\title{
A comparison of macro and micronutrient intake of adult men with different degrees of abdominal obesity
}

\author{
Dayadeep Kaur Grewal \\ Department of Food and Nutrition, Punjab Agricultural University, Ludhiana (Punjab), \\ India \\ Kiran Bains* \\ Department of Food and Nutrition, Punjab Agricultural University, Ludhiana (Punjab), \\ India \\ Harpreet Kaur \\ Department of Food and Nutrition, Punjab Agricultural University, Ludhiana (Punjab), \\ India \\ *Corresponding author. E-mail: kiranbains68@hotmail.com

\begin{abstract}
One hundred and two volunteer male subjects (40-60 years) were divided on the basis of abdominal obesity into three groups - No abdominal obesity i.e. Grade 0 with waist circumference $<94 \mathrm{~cm}$; Abdominal obesity i.e. Grade I with waist circumference: 94.1 to $101.9 \mathrm{~cm}$ and Grade II with waist circumference: $>102 \mathrm{~cm}$. The daily consumption of protein per $\mathrm{kg}$ body weight of the subjects was $1.28,1.21$ and $1.06 \mathrm{~g}$, the protein intake of the subjects with Grade II AO was significantly $(p \leq 0.001)$ lower than the subjects with either no $A O$ or Grade I AO. The carbohydrate: protein ratio varied between a narrow range of 3.48 to 3.69 among the three groups indicating high carbohydrate diets of all the subjects. Energy and fat intake of the subjects in all the groups was much higher than the recommended dietary allowances. The ratio of animal: plant protein intake was almost similar in the subjects with no $A O$ or with Grade I and II AO, the ratio being $0.74,0.81$ and 0.89 , respectively. The micronutrient intake of the studied group was fairly adequate. Out of eight major vitamins, six were more than adequate $(>100 \%)$ or marginally adequate $(>75 \%)$, while the intake of minerals namely calcium, iron and zinc was adequate or nearly adequate among the subjects in the all the three groups, thereby indicating a good mineral and vitamin status of subjects in the present study.
\end{abstract}

Keywords: Abdominal obesity, Carbohydrates, Males, Protein, Waist circumference

\section{INTRODUCTION}

Abdominal or visceral fat in comparison to subcutaneous fat is a matter of concern because it is a major determining factor in many health problems. It has been associated with several metabolic abnormalities and resulted in an enhanced risk of cardiovascular diseases and diabetes. Abdominal adiposity is assessed through waist circumference measurement and is more appropriate to predict metabolic disorders than the determination of general obesity through body mass index (BMI). Since, Visceral fat is related to higher total cholesterol and LDL cholesterol. The lower HDL cholesterol and insulin resistance (Chang et al., 2016) have been observed among adults with abdominal obesity (Després et al., 2008). Although several factors like genetic, metabolic, social, cultural and environment are associated with obesity but a strong association between macronutrient intake and weight change has been

\section{Article Info}

DOI:10.31018/jans.v10i4.1896 Received: September 17, 2018 Revised: October 27, 2018

Accepted: November 1, 2018

\section{How to Cite}

Grewal, D.K. et al. (2018). A comparison of macro and micronutrient intake of adult men with different degrees of abdominal obesity. Journal of Applied and Natural Science, 10 (4): $1173-1179$ 
bohydrates from vegetables and fruits protect against increase in waist-circumferance (Romaguera et al., 2011). It reduces the energy consumption and provides sufficient bulk to the food which makes one feel fuller (Ludwig et al., 1999). In the regulation of body weight, proteins have a great potential to play a key role. The higher intake of animal protein e.g. red meat protected against an increase in waist-circumference and adjusted for BMI (Alkerwi et al., 2015). Studies show that interactive effects of macronutrients are more important for health and aging (Simpson and Raubenheime 2009). It has been highlighted that the balance of protein to non-protein energy in the diet significantly influence the total intake of energy, growth and development, body composition, reproduction, aging, gut microbial ecology, susceptibility to obesity and metabolic disease, immune function and resistance to infectious diseases (Lee et al., 2008, Piper et al., 2011 and Ponton et al., 2011). The present study was conducted to compare the quantitative as well as qualitative intake of macro nutrients of adult men with or without abdominal obesity as it might give insight into role of each macronutrient in the development of abdominal obesity.

\section{MATERIALS AND METHODS}

Selection of subjects: A total of 102 volunteer male subjects belonged to a group of people who regularly visited Punjab Agricultural University campus in Ludhiana, Punjab (India) for either morning and evening walks were enrolled for the study. The subjects were self-motivated for achieving optimum health. They were in the age group of 40 to 60 years and without any major illness. The subjects were divided into three groups on the basis of their abdominal obesity (AO) assessed through their waist circumference measurements (WHO, 2008). Grade 0 (No AO): Waist circumference: $<94.0 \mathrm{~cm}$; Grade I: Waist circumference: 94.1 to $101.9 \mathrm{~cm}$; Grade II: Waist circumference: $>102.0 \mathrm{~cm}$.

General information: General information of the subjects such as age, education, family size, family structure and monthly income of the family was collected.

Development and pretesting of questionnaire: A questionnaire was developed to collect information regarding general information, economic status, physical activity pattern, stress profile, smoking and alcohol use and food consumption pattern. The questionnaire was pretested by $10 \%$ of the subjects to assess its validity. The pretested subjects were excluded from the study.

Macro and micronutrient intake: Dietary intake of was assessed by '24 Hour Recall Method' for three consecutive days. The daily intake of macro as well as micro nutrients was assessed using a software 'Diet Cal' (Kaur, 2018). The adequacy of nutrients was assessed by comparing the nutrient intake with Recommended Dietary Allowances (RDA) of ICMR (2010). Qualitative and quantitative consumption of macronutrients namely proteins, carbohydrates and fats was assessed. The contribution of plant sources such as cereals and pulses and animal sources namely milk and milk products, egg and chicken, meat and fish to total daily protein intake of each subject was assessed. Similarly, ratio of saturated (SFA), monounsaturated (MUFA) and polyunsaturated fatty acids (PUFA) was assessed. The daily intake of available carbohydrates and dietary fibre was also determined.

Statistical analysis: Mean and standard deviation for different parameters were determined using Microsoft Excel (2010) Statistical Analysis Tool Pack. Analysis of Variance (One-way ANOVA) was employed to assess the difference of dietary factors of the subjects in three grades of abdominal obesity.

\section{RESULTS AND DISCUSSION}

General information: The average age of the subjects from the three groups ranged between 49.1 to 51.4 years. The monthly family income of the subjects ranged between Rs. 43,083 to Rs. 56,637 . The family size was in the narrow range of 4.4 to 4.7 family members. The number of children per subject was also close in the three groups, the range being 1.9 to 2.9. Most of the children were living with their families, the average number varied between 1.44 to 1.46 children per subject. The family structure comprised of elderly, adults and children was almost similar in the three groups except in the third group (Grade II), where the number of children were significantly $(p \leq 0.05)$ lesser as compared to those in Grade 0 and I.

In Grade 0, where no AO was observed, majority of the subjects had incomes less than Rs.50,000. The distribution of subjects in Grade I of $A O$ had an almost equal distribution in three categories i.e. $<$ Rs.50,000 (32.5\%), Rs.50,000-1,00,000 (32.5\%) and $>$ Rs. $1,00,000(34 \%)$. The majority of subjects in Grade II of AO had family income <Rs.50,000 (44\%) followed by $36 \%$ of the subjects with family income between Rs.50,000-1,00,000. The findings did not clearly depict any strong relationship between the income status and prevalence of $A O$ among the selected male subjects.

Further, 69,56 and $61 \%$ of the subjects in Grade 0, I and II of AO were working in the government sector. Private sector jobs were performed by very few subjects in Grade 0 and I ( $3 \%$ each), while a good number i.e. $14 \%$ of the subjects in Grade II of $\mathrm{AO}$ were in the private sector jobs. The maximum subjects in the business $(41 \%)$ were in the Grade I of AO. The results present a picture that males in either private jobs or business had a higher prevalence of $\mathrm{AO}$ in comparison to those 
Table 1. Daily intake of macronutrients of the selected male subjects with different grades of abdominal obesity.

\begin{tabular}{lllll}
\hline Nutrients & $\begin{array}{l}\text { Grade } \mathbf{0} \\
\mathbf{n = 3 2}\end{array}$ & $\begin{array}{l}\text { Grade I } \\
\mathbf{n = 3 4}\end{array}$ & $\begin{array}{l}\text { Grade II } \\
\mathbf{n = 3 6}\end{array}$ & P value \\
\hline Protein $(\mathrm{g})$ & $89.98 \pm 32.32$ & $93.51 \pm 29.26$ & $95.85 \pm 25.26$ & $0.71^{\text {NS }}$ \\
Protein per kg body weight $(\mathrm{g})$ & $1.28 \pm 0.42$ & $1.21 \pm 0.34$ & $1.04 \pm 0.29$ & $0.03^{* *}$ \\
Carbohydrates $(\mathrm{g})$ & $313.05 \pm 71.97$ & $311.14 \pm 64.68$ & $340.96 \pm 79.94$ & $0.16^{\mathrm{NS}}$ \\
CHO:Protein ratio & 3.65 & 3.48 & 3.69 & \\
Total fat (g) & $117.03 \pm 42.68$ & $138.32 \pm 41.24$ & $124.70 \pm 33.28$ & $0.08^{\mathrm{NS}}$ \\
Energy (Kcal) & $2878 \pm 1169$ & $2912 \pm 576$ & $2981 \pm 611$ & $0.86^{\mathrm{NS}}$ \\
\hline
\end{tabular}

Values are Mean \pm SD; AO: Abdominal Obesity; Values in parenthesis are percentages; NS: Non-significant; ** Significant at 5\%; Grade 0 of AO: Waist Circumference: $<94 \mathrm{~cm}$; Grade I of AO: Waist Circumference: 94.1 to $101.9 \mathrm{~cm}$; Grade II of AO: Waist Circumference: $>102 \mathrm{~cm}$.

Table 2. Qualitative protein consumption in terms of vegetable and plant protein sources by selected male subjects with different grades of abdominal obesity.

\begin{tabular}{|c|c|c|c|c|}
\hline Protein Sources & $\begin{array}{l}\text { Grade } 0 \\
\mathrm{n}=32\end{array}$ & $\begin{array}{l}\text { Grade } 1 \\
\mathrm{n}=34\end{array}$ & $\begin{array}{l}\text { Grade } 2 \\
\mathrm{n}=36\end{array}$ & $P$ value \\
\hline \multicolumn{5}{|c|}{ Plant and animal sources of protein } \\
\hline Pulses (g) & $8.98 \pm 4.14$ & $9.47 \pm 4.3$ & $9.52 \pm 5.23$ & $0.89^{\mathrm{NS}}$ \\
\hline Cereals (g) & $27.61 \pm 8.52$ & $26.19 \pm 8.15$ & $25.19 \pm 7.04$ & $0.45^{\mathrm{NS}}$ \\
\hline Total $(\mathrm{g})$ & $36.59 \pm 12.66$ & $35.66 \pm 12.45$ & $37.71 \pm 12.27$ & - \\
\hline Milk and milk products $(\mathrm{g})$ & $20.26 \pm 9.24$ & $21.75 \pm 11.38$ & $19.61 \pm 10.77$ & $0.74^{\mathrm{NS}}$ \\
\hline Eggs (g) & $1.58 \pm 4.55$ & $2.31 \pm 4.72$ & $2.74 \pm 6.20$ & $0.65^{\mathrm{NS}}$ \\
\hline Chicken/Meat/Fish (g) & $5.12 \pm 10.92$ & $7.73 \pm 13.27$ & $8.36 \pm 15.26$ & $0.57^{\mathrm{NS}}$ \\
\hline Total $(\mathrm{g})$ & $26.96 \pm 24.71$ & $31.79 \pm 29.37$ & $30.71 \pm 32.23$ & - \\
\hline Animal: Plant protein ratio & 0.74 & 0.89 & 0.81 & - \\
\hline \multicolumn{5}{|l|}{ Type of carbohydrates } \\
\hline Available $(\mathrm{g})$ & $227.11 \pm 71.97$ & $220.61 \pm 51.65$ & $240.77 \pm 50.78$ & $0.288^{\mathrm{NS}}$ \\
\hline Dietary fibre (g) & $48.91 \pm 13.54$ & $44.29 \pm 10.94$ & $51.14 \pm 12.15$ & $0.064^{*}$ \\
\hline Total $(\mathrm{g})$ & $276.02 \pm 85.85$ & $264.9 \pm 62.59$ & $291.91 \pm 62.93$ & - \\
\hline \multicolumn{5}{|l|}{ Fatty acids } \\
\hline Saturated $(\mathrm{g})$ & $38.83 \pm 14.46$ & $44.95 \pm 13.58$ & $41.83 \pm 17.65$ & $0.27^{\mathrm{NS}}$ \\
\hline Monounsaturated (g) & $23.30 \pm 14.62$ & $26.16 \pm 13.63$ & $22.60 \pm 12.29$ & $0.51^{\mathrm{NS}}$ \\
\hline Polyunsaturated $(\mathrm{g})$ & $23.89 \pm 12.39$ & $26.70 \pm 11.17$ & $25.52 \pm 12.29$ & $0.57^{\mathrm{NS}}$ \\
\hline Total $(\mathrm{g})$ & $86.02 \pm 41.47$ & $97.81 \pm 38.38$ & $89.95 \pm 42.23$ & - \\
\hline
\end{tabular}

$\mathrm{n}=102$; Values are Mean \pm SD; AO: Abdominal Obesity; Values in parenthesis are percentages; NS: Nonsignificant; Grade 0 of AO: Waist Circumference: <94 cm; Grade I of AO: Waist Circumference: 94.1 to 101.9 $\mathrm{cm}$; Grade II of AO: Waist Circumference: $>102 \mathrm{~cm}$.

Table 3. Daily intake of vitamins and minerals by the selected male subjects with different grades of abdominal obesity.

\begin{tabular}{|c|c|c|c|c|}
\hline Vitamins and Minerals & $\begin{array}{l}\text { Grade } 0 \\
n=32\end{array}$ & $\begin{array}{l}\text { Grade I } \\
n=34\end{array}$ & $\begin{array}{l}\text { Grade II } \\
n=36\end{array}$ & $P$ value \\
\hline \multicolumn{5}{|l|}{ Vitamins } \\
\hline Thiamine (mg) & $1.74 \pm 0.88$ & $1.53 \pm 0.40$ & $1.68 \pm 0.40$ & $0.34^{\mathrm{NS}}$ \\
\hline Riboflavin (mg) & $1.10 \pm 0.36$ & $1.04 \pm 0.38$ & $1.13 \pm 0.35$ & $0.57^{\mathrm{NS}}$ \\
\hline Niacin (mg) & $12.47 \pm 7.39$ & $11.33 \pm 4.99$ & $12.44 \pm 5.07$ & $0.42^{\mathrm{NS}}$ \\
\hline Pantothenic acid (mg) & $6.09 \pm 2.38$ & $5.72 \pm 1.56$ & $6.24 \pm 1.48$ & $0.47^{\mathrm{NS}}$ \\
\hline Pyridoxine (mg) & $1.76 \pm 0.57$ & $1.65 \pm 0.55$ & $1.96 \pm 0.54$ & $0.06^{*}$ \\
\hline Biotin $(\mu \mathrm{g})$ & $26.01 \pm 9.45$ & $26.38 \pm 10.62$ & $28.29 \pm 11.89$ & $0.63^{\mathrm{NS}}$ \\
\hline Folic acid $(\mu \mathrm{g})$ & $363.30 \pm 156.09$ & $326.79 \pm 106.02$ & $371.71 \pm 99.36$ & $0.27^{\mathrm{NS}}$ \\
\hline Vitamin $B_{12}(\mu \mathrm{g})$ & $0.04 \pm 0.06$ & $0.08 \pm 0.08$ & $0.1 \pm 0.07$ & $055^{\mathrm{NS}}$ \\
\hline Ascorbic acid (mg) & $129.37 \pm 112.74$ & $137.24 \pm 83.07$ & $142.56 \pm 84.19$ & $0.84^{\mathrm{NS}}$ \\
\hline Retinol $(\mu \mathrm{g})$ & $230.73 \pm 119.67$ & $240.88 \pm 162.86$ & $306.66 \pm 166.18$ & $0.08^{*}$ \\
\hline Vitamin D $(\mu g)$ & $61.99 \pm 32.22$ & $55.17 \pm 19.74$ & $61.42 \pm 25.08$ & $0.49^{\mathrm{NS}}$ \\
\hline Vitamin E (mg) & $2.62 \pm 1.78$ & $2.80 \pm 1.99$ & $2.89 \pm 2.17$ & $0.85^{\mathrm{NS}}$ \\
\hline Carotenoids $(\mu \mathrm{g})$ & $15531.70 \pm 7896.74$ & $1704.26 \pm 7715.39$ & $17291.00 \pm 7684.42$ & $0.36^{\mathrm{NS}}$ \\
\hline \multicolumn{5}{|l|}{ Minerals } \\
\hline Calcium (mg) & $1097 \pm 340$ & $1078 \pm 453$ & $1128 \pm 475$ & $0.88^{\mathrm{NS}}$ \\
\hline Iron (mq) & $20.75 \pm 9.90$ & $18.37 \pm 5.21$ & $20.37 \pm 4.88$ & $0.32^{\mathrm{NS}}$ \\
\hline Zinc (mg) & $12.53 \pm 5.80$ & $10.96 \pm 2.77$ & $12.01 \pm 2.75$ & $0.26^{\mathrm{NS}}$ \\
\hline
\end{tabular}

$\mathrm{n}=100$; Values are Mean \pm SD; AO: Abdominal Obesity; NS: Non-significant; Grade 0 of AO: Waist Circumference: <94 cm; Grade I of AO: Waist Circumference: 94.1 to $101.9 \mathrm{~cm}$; Grade II of AO: Waist Circumference: $>102 \mathrm{~cm}$. 


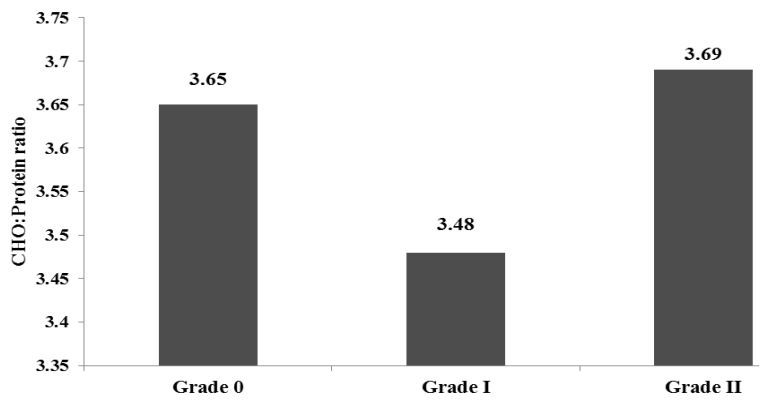

Fig. 1. Ratio of carbohydrates and protein ratio in the diets of the selected male subjects with different grades of abdominal obesity.

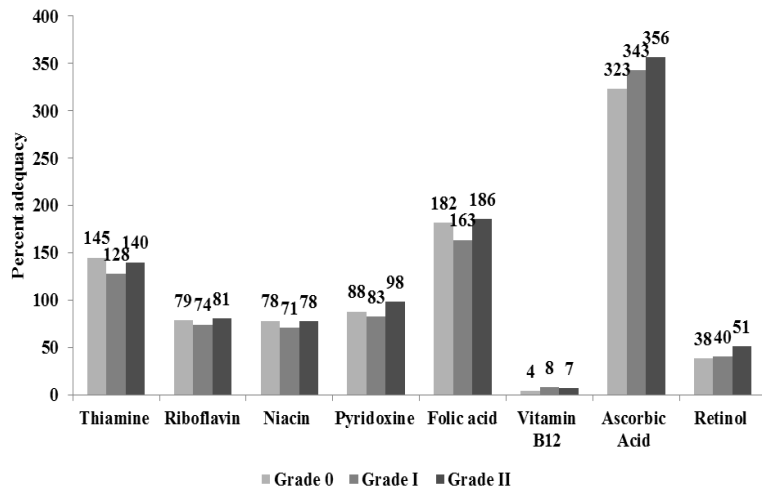

Fig. 3. Percent adequacy of vitamins by the selected male subjects with different grades of abdominal obesity.

working in the government sector.

Daily macronutrient consumption: The data of daily intake of macronutrient namely proteins, carbohydrates and fats as well as energy by the subjects in Grade 0, I and II of AO has been mentioned in table 1 . The carbohydrate: protein ration has been shown in fig. 1 . The daily consumption of protein by the subjects in Grade 0, I and II was $89.98,93.51$ and $95.85 \mathrm{~g}$, respectively. On calculating the daily protein intake per kg body weight of the subjects, the corresponding values were $1.28,1.21$ and $1.06 \mathrm{~g}$. The statistical analysis clearly revealed that the subjects with Grade II AO (WC: $>102 \mathrm{~cm})$ was significantly $(p \leq 0.05)$ higher per kg body weight than the subjects with either no AO or AO of Grade I. In a study by CamposNonato et al., (2017), the group on high protein diet lost significantly more weight than the one consumed standard protein diet. The daily carbohydrate intake of the subject in Grade 0, I and II of AO varied between 313.05 to $340.96 \mathrm{~g}$. On calculating the carbohydrate: protein ratio, it was found that it varied between a narrow range of 3.48 to 3.69 among the three groups. Carbohydrate: protein ratio higher than 2.5 indicates a high carbohydrate diet and the subjects in all the three groups in the present study were consuming high carbohydrate diets. Feng et al., (2015) found that high total carbohydrate and carbohydrates from

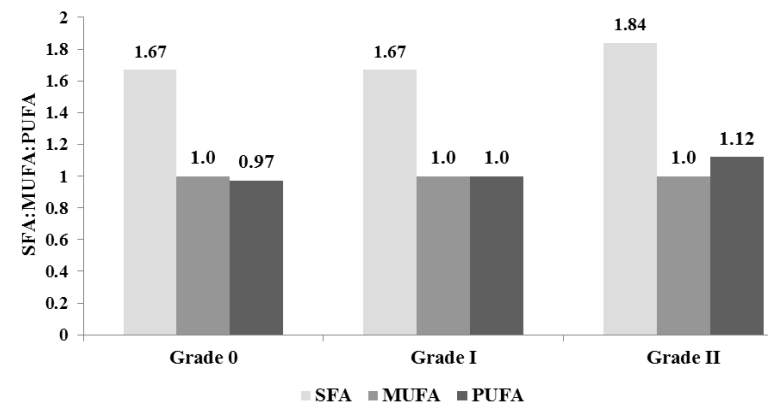

Fig. 2. Ratio of saturated, mono unsaturated and polyunsaturated fatty acids in the diets of the selected male subjects with different grades of abdominal obesity.

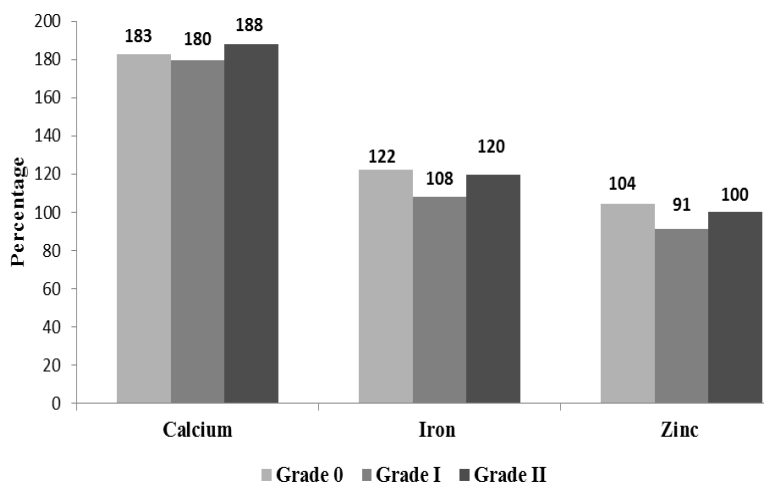

Fig. 4. Percent adequacy of minerals by the selected male subjects with different grades of abdominal obesity.

starchy foods intakes were associated with hyperlipidemia and metabolic syndrome. The carbohydrate cut-off value being $220 \mathrm{~g}$ from starchy foods. Kitabchi et al., (2013) showed that the subjects on high protein-low carbohydrate diet exhibited greater improvement in markers of insulin sensitivity and $\beta$-cell function, oxidative stress, lipid peroxidation, and inflammatory cytokines than the high carbohydrate-low protein diet. Jung and Choi (2017) suggested that low-carbohydrate diets help in significant weight loss and a reduction in plasma glucose, HbA1c and low density lipoproteincholesterol (LDL-C). In the present study, carbohydrate intake of subjects was higher than all other related studies. Dehghan et al., (2017) showed that higher carbohydrate intake was associated with higher risk of total mortality in both Asian and non-Asian countries. The daily energy intake of the subjects in Grade 0, I and II of AO was 2878, 2912 and $2981 \mathrm{kcal}$, respectively. The subjects in all the three groups had intake higher than the RDA of energy for both sedentary and moderate workers (ICMR, 2010). The higher intake of macronutrients and energy has been observed in the present study indicating that the diets of the subjects were more than adequate.

Qualitative intake of proteins, carbohydrates and fats have been shown in table 2 . The subjects in three groups consumed more protein from plant 
sources ( 36.59 to $37.71 \mathrm{~g}$ ) than the animal sources $(26.96$ to $30.71 \mathrm{~g})$. There have been inconsistent results on whether the source of protein i.e. plant or animal has different effects on obesity. Lin et al., (2011) reported that plant protein intake was inversely correlated with BMI and WC in Belgian adults while Alkerwi et al., (2015) reported that the risk of abdominal obesity increases with increasing intake of meat and fish. But Park et al., (2018) found that both types of protein were inversely associated with obesity. The intake of available carbohydrates by the subjects varied between 220.61 to $240.77 \mathrm{~g}$ in the subjects with either no AO or AO of Grade I or II. The corresponding range for dietary fibre was found to be 44.19 to $51.14 \mathrm{~g}$. Merchant et al., (2009) reported that sufficient amount of carbohydrates in the range of 290 to $310 \mathrm{~g}$ per day is needed to reduce obesity.

Moreover, the traditional insoluble fibres are required to add bulk as well as rapidly fermentable, viscous fibres to bring cholesterol lowering effect which leads to beneficial health effect in obesity. The saturated, monounsaturated and polyunsaturated fatty acid intake of the subject in the three groups did not vary significantly $(p \leq 0.001)$. However on calculating the ratio of SFA:MUFA:PUFA, it was found that the ratios of the three fatty acids were $1.67: 1: 0.97,1.67: 1: 1$ and $1.84: 1: 1.12$ by the subjects in Grade $0, \mathrm{I}$ and II of $\mathrm{AO}$, respectively (Fig. 2).

Daily micronutrient consumption: The daily intake of B-vitamins, ascorbic acid, retinol, vitamin $D$, vitamin E, carotenoids and minerals namely, calcium, iron and zinc of the subjects in Grade 0, I and II of $\mathrm{AO}$ has been given in table 3 . The adequacy of vitamins and minerals has been depicted in Fig. 3 and 4, respectively. The intake of thiamine, folic acid, ascorbic acid was more than adequate. The percent adequacy being 128-145, 163186 and $325-356 \%$, respectively for the subjects in the three groups, respectively.

On the other hand, riboflavin, niacin and pyridoxine were marginally adequate $(>75 \%$ of RDA) while inadequacy of vitamin $\mathrm{B}_{12}$ and retinol were observed in all the three groups. No significant difference has been found in the daily intake of vitamins in the subjects except for pyridoxine and tocopherols which was significantly $(p \leq 0.1)$ higher in the subjects of Grade II of $A O$ as compared to the subjects with no AO or Grade I of AO. In contrary to this, the intake of minerals namely, calcium, iron and zinc was adequate or nearly adequate among the subjects in the all the three groups, the percent adequacy being in the range of $180-188,108-122$ and $91-104 \%$, respectively. The results showed that the vitamin intake of the studied group was fairly adequate, however, out of eight major vitamins, six were more than adequate $(>100 \%)$ or marginally adequate $(>75 \%)$, thereby indicating a good mineral and vitamin sta- tus of subjects in present study.

In a study by García et al., (2009), it was shown that micronutrient deficiencies may be important contributors to the observed increases in obesity prevalence because they are part of the range of metabolic disorders that are associated with obesity. Damms-Machado et al., (2012) demonstrated an insufficient dietary micronutrient supply of retinol, ß-carotene, vitamin D, vitamin $E$, vitamin $C$, folate, iron, and calcium in obese individuals. Similarly, Galan et al., (2005) showed that serum beta -carotene and vitamin C concentrations were lower in obese subjects. Aasheim et al., (2008) reported low concentrations of vitamin B-6, vitamin C, 25-hydroxyvitamin D, and vitamin E are prevalent in morbidly obese Norwegians while the status of vitamins A, B-1, B-2, and B-12 and of folic acid was adequate in most of the patients. According to Via (2012), vitamins and minerals such as vitamin $\mathrm{D}$, chromium, biotin, thiamine and vitamin $C$, are known to be deficient at relatively high rates in obese individuals and in diabetic patients. Gascón-Vila et al (1997) showed that BMI and energy intake significantly influenced serum alpha-tocopherol concentration. In another study by Wallström et al., (2001), serum beta-carotene concentration was not significantly associated with central adiposity but serum alpha-tocopherol concentration was positively correlated with obesity in men.

\section{Conclusion}

The study revealed that the subjects in all the three groups i.e. Grade 0, I and II had higher intake of protein, fats and energy. The protein intake per $\mathrm{kg}$ body weight was significantly lower in the subjects with grade II abdominal obesity (1.04 g), thus showed that higher protein intake was inversely related to abdominal obesity. The $\mathrm{CHO}$ : protein ratio indicated that subjects were consuming more carbohydrates in comparison to proteins in all the three groups (3.48-3.69). Daily intake of fat and energy was much higher in all the groups in comparison to the recommended dietary allowances, the range being 117.03 to $138.32 \mathrm{~g}$ for fat and 2878 to $2981 \mathrm{kcal}$ for energy. It has been observed that the diets high in macronutrients due to larger meal size may contribute to a good intake of other nutrients such as vitamins and minerals.

\section{REFERENCES}

1. Aasheim, E.T., Hofso, D., Hjelmesaeth, J., Birkeland, K.I. and Bohmer, T. (2008). Vitamin status in morbidly obese patients: a cross-sectional study. Am. J. Clin. Nutr., 87: 362-69.

2. Alkerwi, A., Sauvageot, N., Buckley, J., Donneau, A., Albert, A., Guillaume, M. and Crichton, G. (2015). The potential impact of protein intake on global and abdominal obesity: evidence from the observation of cardiovascular risk factors in Luxembourg (ORISCAV -LUX) study. Public Health Nutr., 18: 1831-38. 
3. Campos-Nonato, I., Hernandez, L. and Barquera, S. (2017). Effect of a high-protein diet versus standardprotein diet on weight loss and biomarkers of Metabolic Syndrome: A randomized clinical trial. Obes. Facts, 10: 238-51.

4. Chang, J. W., Chen, H. L., Su, H. J., \& Lee, C. C. (2016). Abdominal obesity and insulin resistance in people exposed to moderate-to-high levels of dioxin. PloS one, 11(1) : e0145818.

5. Damms-Machado, A., Weser, G. and Bischoff, S.C. (2012). Micronutrient deficiency in obese subjects undergoing low calorie diet. Nutr. J., 11: 34.

6. Dehghan, M., Mente, A., Zhang, X., Swaminathan, S., Li, W., Mohan, V., Iqbal, R., Kumar, R., WentzelViljoen, E., Rosengren, A., Amma, L.I., Avezum, A., Chifamba, J., Diaz, R., Khatib, R., Lear, S., Lopez -Jaramillo, P., Liu, X., Gupta, R., Mohammadifard, N., Gao, N., Oguz, A., Ramli, A. S., Seron, P., Sun, Y., Szuba, A., Tsolekile, L., Wielgosz, A., Yusuf, R., Hussein Yusufali, A., Teo, K.K., Rangarajan, S., Dagenais, G., Bangdiwala, S.I., Islam, S., Anand, S.S. and Yusuf, S. (2017). Associations of fats and carbohydrate intake with cardiovascular disease and mortality in 18 countries from five continents (PURE): A prospective cohort study. Lancet, 390: 2050-62.

7. Després, J.P., Arsenault, B.J., Côté, M., Cartier, A. and Lemieux, I. (2008). Abdominal obesity: The cholesterol of the 21st century? Can. J. Cardiol.,24:7D12D

8. Feng, R., Du, S., Chen, Y., Zheng, S., Zhang, W., Na, G., Li, Y. and Sun, C. (2015). High carbohydrate intake from starchy foods is positively associated with metabolic disorders: a Cohort Study from a Chinese population. Sci. Rep., 5: 16919.

9. Galan, P., Viteri, F.E., Bertrais, S., Czernichow, S., Faure, H., Arnaud, J., Ruffieux, D., Chenal, S., Arnault, N., Favier, A., Roussel, A.M. and Hercberg, S. (2005). Serum concentrations of beta-carotene, vitamins $\mathrm{C}$ and $\mathrm{E}$, zinc and selenium are influenced by sex, age, diet, smoking status, alcohol consumption and corpulence in a general French adult population. Eur. J. Clin. Nutr., 59:1181-90

10.García, O.P., Long, K.Z. and Rosado, J.L. (2009) Impact of micronutrient deficiencies on obesity. Nutr. Rev., 67: 559-72.

11.Gascón-Vila, P., Garcia-Closas, R., Serra-Majem, L., Pastor, M.C., Ribas, L., Ramon, J.M., MarinéFont, A. and Salleras, L. (1997). Determinants of the nutritional status of vitamin $E$ in a non-smoking Mediterranean population. Analysis of the effect of vitamin $E$ intake, alcohol consumption and body mass index on the serum alpha-tocopherol concentration. Eur. J. Clin. Nutr., 51: 723-28.

12.ICMR (2010). Nutrient requirements and recommended dietary allowances for Indians. Indian Council of Medical Research (ICMR), National Institute of Nutrition, Hyderabad.

13.Jung, C.H. and Choi, K.M. (2017). Impact of highcarbohydrate diet on metabolic parameters in patients with type 2 diabetes. Nutrients, 9: 322.

14.Kaur, G. (2018) DietCal: A tool for Dietary Assessment and Planning. Profound Tech Solutions. Department of Dietetics, AlIMS, New Delhi, India.

15.Kitabchi, A.E., McDaniel, K.A., Wan, J.Y., Tylavsky, F.A., Jacovino, C.A., Sands, C.W., Nyenwe, E.A. and Stentz, F.B. (2013). Effects of high-protein versus high-carbohydrate diets on markers of $\beta$-Cell function, oxidative stress, lipid peroxidation, proinflammatory cytokines, and adipokines in obese, premenopausal women without diabetes: A randomized controlled trial. Diabetes Care, 36: 1919-25.

16.Lee, K.P., Simpson, S.J., Clissold, F.J., Brooks, R., Ballard, J.W., Taylor, P.W., Soran, N. and Raubenheimer, D. (2008). Lifespan and reproduction in Drosophila: New insights from nutritional geometry. Proc. Natl. Acad. Sci., 105: 2498-2503.

17.Ley, S.H., Hamdy, O., Mohan, V. and Hu, F.B. (2014). Prevention and management of type 2 diabetes: dietary components and nutritional strategies. Lancet, 383: 1999-2007.

18.Lin, Y., Bolca, S., Vandevijvere, S., De Vriese, S., Mouratidou, T., De Neve, M., Polet, A., Van Oyen, H., Van Camp, J., De Backer, G., De Henauw, S. and Huybrechts, I. (2011). Plant and animal protein intake and its association with overweight and obesity among the Belgian population." Br. J. Nutr., 105: 1106-16.

19.Ludwig, D.S. (2000). Dietary glycemic index and obesity. J. Nutr., 130: 280-83.

20.Ludwig, D.S., Majzoub, J.A., Al-Zahrani, A., Dallal, G.E., Blanco, I. and Roberts, S.B. (1999). High glycemic index foods, overeating and obesity. Pediatr., 103: 261-66.

21.Merchant, A.T., Vatanparast, H., Barlas, S., Dehghan, M., Shah, S.M., De Koning, L. and Steck, S.E. (2009). Carbohydrate intake and overweight and obesity among healthy adults. $J$. Am. Diet. Assoc., 109: 1165-72.

22.Nikbazm, R., Rafie, M., Ghanebasiri, M., Nourshahi, N., Sotoudeh, G., Eshranghian, M., Jalali, M. and Koohdani, F. (2013). The relationship between waist circumference and macronutrient intake in patients with type 2 diabetes in Tehran. Intl. Res. J. Appl. Basic. Sci., 5: 1021-24.

23.Park, K.B., Park, H.A., Kang, J.H., Kim, K., Cho, Y.G. and Jang, J. (2018). Animal and Plant Protein Intake and Body Mass Index and Waist Circumference in a Korean Elderly Population. Nutrients, 10: E577.

24.Piper, M.D., Partridge, L., Raubenheimer, D. and Simpson, S.J. (2011). Dietary restriction and aging: A unifying perspective. Cell Metab., 14: 154-60.

25.Ponton, F., Wilson, K., Cotter, S.C., Raubenheimer, D. and Simpson, S.J. (2011). Nutritional immunology: A multi-dimensional approach. PLoS Pathog., 7: e1002223.

26.Roberts, S.B. (2000). High-glycemic index foods, hunger and obesity: Is there a connection? Nutr. Rev., 58: 163-69.

27.Romaguera, D., Ängquist, L., Du, H., Jakobsen, M.U., Forouhi, N.G., Halkjær, J., Feskens, E. J., Van der A.D., Masala, G., Steffen, A., Palli, D., Wareham, N.J., Overvad, K., Tjønneland, A., Boeing H, Riboli, E. and Sørensen, T.I. (2011). Food composition of the diet about changes in waist circumference adjusted for body mass index. PLOS ONE, 6: e23384.

28.Simpson, S.J. and Raubenheimer, D. (2009). Macronutrient balance and lifespan. Aging, 1: 875-80.

29.Via, M. (2012). The Malnutrition of obesity: Micronutrient deficiencies that promote diabetes. ISRN Endocrinol., 2012: 103472.

30.Wallström, P., Wirfält, E., Lahmann, P.H., Gullberg, B., Janzon, L. and Berglund, G. (2001). Serum con- 
Grewal, D.K. et al. / J. Appl. \& Nat. Sci. 10 (4): 1173 -1179 (2018)

centrations of beta-carotene and alpha-tocopherol are associated with diet, smoking, and general and central adiposity. Am. J. Clin. Nutr., 73: 777-85.
31.WHO (2008). Waist Circumference and Waist-Hip Ratio: Report of a WHO Expert Consultation World Health Organization, Geneva. 